Revista Internacional de Sociología (RIS)

Vol.67, No 3, Septiembre-Diciembre, 609-629, 2009

ISSN: 0034-9712

elSSN: 1988-429X

DOI:10.3989/ris.2008.03.24

\title{
ANALYZING TEMPORAL VARIATION IN THE LETHALITY OF ETA
}

\author{
ANÁLISIS DE LA VARIACIÓN TEMPORAL EN LA LETALIDAD DE ETA
}

\author{
IgNACIO SÁnCHEZ-CuENCA \\ Juan March Institute and Complutense University of Madrid. Spain \\ isc@ceacs.march.es
}

\begin{abstract}
This article analyzes time variation in the lethal violence of the terrorist organization ETA. Given the dynamic structure of the time series of fatalities, I look at the effect of a number of independent variables (the celebration of different types of elections, anti-ETA activity by extreme right-wing organizations and the GAL, police arrests, and other relevant events, such as the referendums on the Constitution and the Statute of Autonomy of Guernica). To do so, I have estimated several ARIMA models using the time series of fatalities between 1968 and 2007. Moreover, the results obtained are complemented by a historical-political analysis of the period of maximum violence, which took place during the Spanish transition to democracy.
\end{abstract}

\section{Additional KeYWords}

ARIMA models, Nationalism, Political Violence, Spanish Transition, Terrorism.

\section{RESUMEN}

Este artículo analiza la variación temporal en la violencia letal de la organización terrorista ETA. Dada la estructura dinámica de la serie temporal de víctimas mortales, se estudia el efecto de una serie de variables independientes (celebración de distintos tipos de elecciones, actividad anti-ETA de la extrema derecha y del GAL, detenciones policiales y sucesos especiales como los referendos sobre la Constitución o el Estatuto de Autonomía de Guernica). Para ello, se estiman diversos modelos ARIMA con la serie trimestral de víctimas mortales entre 1968 y 2007. Además, se completan los resultados obtenidos con un análisis histórico-político del periodo de máxima violencia durante la transición a la democracia.

\section{Palabras Clave Adicionales}

Modelos ARIMA, Nacionalismo, Transición española, Terrorismo, Violencia política. 


\section{INTRODUCTION $^{1}$}

ETA (Euskadi ta Askatasuna, "Basque Homeland and Freedom") is the longest surviving terrorist organization in Europe and one of the oldest in the world. Founded in 1959, ETA did not begin killing until 1968. More than forty years later, ETA is still killing. Throughout this extensive period, there have been tremendous variations in the intensity of lethal violence. In this study, I try to explain such variations in three different but complementary ways. First of all, I describe the cycle of violence in terms of four distinct phases each broadly corresponding to the various strategic phases which ETA has undergone. Secondly, I present a time-series analysis whereby, taking into account the dynamic structure of the series as well as the four phases just mentioned, I try to determine the effect on violence of a number of independent variables, such as the celebration of elections, particularly relevant political events (the referendums on the Constitution and the Statute of Guernica), the so-called "dirty" war against ETA and the anti-terrorist activity of the State, measured by the number of arrests made. Thirdly, I carry out a detailed examination of the period in which ETA was most active, the Spanish transition to democracy. By means of a historical analysis of political events, I try to explain why ETA's offensive began so late on in the transition, towards the end of 1977, and why it came to such a sudden end in 1981.

The article thus combines statistical tools and historical-political narration. The statistical analysis allows us to identify the principal phases of ETA's cycle of violence and to determine the effect of some independent variables that a purely historical focus could not detect. On the other hand, the historical-political analysis is essential to explain in somewhat more depth the phase of violence which took place during the transition, the period with the greatest number of fatalities in which ETA's great offensive is launched and later exhausted.

In the literature on ETA, there are a number of previous works which statistically analyze the phenomenon of terrorism. Almost all of them (Barros, 2003; Barros, Passos and Gil-Alana, 2006; Barros and Gil-Alana, 2006) are econometric exercises which ignore political and sociological considerations ${ }^{2}$. The only research containing a dynamic

\footnotetext{
${ }^{1}$ This article is part of a research project financed by the Spanish Ministry of Science and Technology (SEJ 2006-12462) (more information on the project at www.march.es/ceacs/dtv). I am thankful for comments to Paloma Aguilar, Luis de la Calle, and Patxo Unzueta.

${ }^{2}$ Barros (2003), for example, first of all states that the PSOE came to power in 1976 and then goes on to say that they were in power during the period 1972-96, given that, according to him, Franco's dictatorship ended in 1972. Moreover, he claims that the negotiations in Algiers were in 1992; they were in 1989. Barros uses annual data of fatalities and kidnappings from the Home Office (Ministerio de Interior). Barros, Passos and Gil-Alana (2006) use data on attacks taken from ITERATE, the database on international terrorism which does not contain data on national or domestic attacks and as such hardly a reliable source for an analysis of ETA violence. Barros and Gil-Alana (2006) represents an important step forward given that this work is based on monthly data of fatalities and provides a more in-depth look at political considerations, introduced as co-variables.
} 
statistical analysis based on the hypotheses present in the literature on ETA is that of Martínez Herrera (2002, 2007). His analyses, however, have been carried out using annual series of fatalities, which very much reduce the number of observations; and the main focus is the effects of anti-terrorist policies rather than the cycle of violence itself. In this article, my main concern is ETA's violence. Using quarterly data taken from a new database on the mortal victims of ETA, we can add 160 observations between 1968 and 2007. Given the greater number of cases, the statistical analysis is more reliable and it also allows us to test hypotheses that with annual observations would not be possible. The statistical method used to analyze the time series is ARIMA models.

Although the body of literature on ETA has grown substantially over the last ten years dealing with very diverse questions, such as ETA's recruitment and reproduction processes, its strategic development, its networks of popular support, patterns of victim selection, or anti-terrorist policies and their effects on ETA (Avilés, 2005; Calleja and Sánchez-Cuenca, 2006; De la Calle, 2007; De la Calle and Sánchez-Cuenca, 2004; Domínguez, 1998a; 1998b; Elorza, 2000; Jaime, 2002; Letamendía, 1994; Llera, 1992; Beck, 2005; Mata, 1993; Reinares, 1990; Reinares and Jaime, 2000; Sánchez-Cuenca, 2001; 2007a; Shabad and Llera, 1995; Tejerina, 2001), it is clear, as mentioned above, that important holes remain in our understanding of the time variation in ETA's lethal violence ${ }^{3}$.

This article aims to fill these holes. There are three main sections. The first describes the distinct phases of ETA's cycle of terrorism and whether these coincide, or not, with the distinct strategic phases which the organization has undergone. The second contains the time-series analysis. The third introduces historic and political considerations which complement the previous statistical analysis.

\section{FOUR PHASES IN ETA'S LETHAL VIOLENCE}

Figure 1 shows the quarterly sequence of fatalities of Basque nationalist terrorism from 1968 to 2007 . It has been constructed using the database of fatalities created by myself and Luis de la Calle (available at www.march.es/dtv). Figure 1 includes all the fatalities caused by Military ETA (ETA-m), Political-Military ETA (ETA-pm), the Anti-Capitalist Autonomous Commands (the CAA-Comandos Autónomos Anticapitalistas) and three smaller organizations with one fatality each (ETA-pm VIII Assembly, a splinter of ETA-pm; Gatzaka, a splinter of the CAA; and Iraultza, an anti-imperialist faction ${ }^{4}$ ). I believe that with regard strategies and objectives there is a fundamental continuity between the

\footnotetext{
${ }^{3}$ For a brief summary of the literature see Sánchez-Cuenca (2007b).

${ }^{4}$ As such, killings not included are those which cannot be attributed to any one organization in particular, such as the two people killed by kale borroka in 1987 or the two ertzainas killed by Mikel Otegi in 1995. A more detailed explanation of the criteria used here can be found in Calleja and Sánchez-Cuenca (2007).
} 
original ETA (before the split of 1974) and ETA-m and as such wherever I mention ETA in this article, I refer to the original ETA up to the end of 1974 and to ETA-m thereafter. In this sense, ETA is responsible for $93 \%$ of the total killings of Basque nationalist terrorism (777 victims out of a total of 836 ).

From the data in Figure 1 and our knowledge of ETA's strategic development, it is possible to distinguish four main phases based on the number of fatalities ${ }^{5}$. The first phase begins with the killing of Carrero Blanco and his two body guards on 20 December 1973 and ends with the celebration of the first democratic elections in June 1977. At this point the level of violence was still low, with less than 10 fatalities per quarter. From the mid-sixties ETA had felt that violence could bring about popular insurrection against Franco's regime through action-repression-action strategy, according to which violence would bring about a disproportionately repressive response from the State which in turn would increase popular support for the terrorist group, and which ultimately would allow ETA to increase its offensive capacity. Despite there being a great deal of labor conflict during these years, it is clear that the Basques did not pay a great deal of attention to ETA's revolutionary message. The death of Franco barely affected the pattern of lethal attacks of the terrorists. Indeed, Figure 1 allows us to corroborate that there was no significant increase whatsoever in the intensity of lethal terrorist violence in the time stretching between Franco's death and the celebration of the first democratic general elections in June 1977.

ETA's great offensive against the State begins after the celebration of these first elections, at the end of 1977. This marks the beginning of the second phase, which can be described strategically as a war of attrition (Sánchez-Cuenca 2001: Cap.3; 2007a). ETA no longer expects the masses to rise. Instead, it decides to use violence as a means of inflicting a cost on the State for refusing to satisfy ETA's demands contained in the KAS Alternative (the most important being the right to self-determination, the withdrawal of the Spanish army and police from the Basque Country, and total amnesty). ETA is now operating under the assumption that if the cost inflicted on the State, in terms of human lives, financial extortion and property destruction, is sufficiently high it will eventually give in. The State, on the other hand, attempts to bring the violence to an end by arresting as many terrorists as it can in order to force ETA to the point where it prefers to pursue its ends by non-violent means.

The great offensive launched in 1977 lasts until the end of 1980. In 1981 there is a very noticeable reduction in the number of fatalities. This reduction, however, is not the result of a change in strategy; it is rather forced by the State's counterterrorist activity. In the third phase, which is still within the context of a war of attrition, a certain equilibrium is reached between ETA's terrorist activity and the repressive activity of the State. As such,

\footnotetext{
${ }^{5}$ I do not consider the period 1968-73 to be relevant in terms of violence, as there is virtually no lethal activity by ETA registered at this time. The same applies to the years following 2003, when again there are very few attacks involving killings. The four phases to which I refer thus belong to the period 1973-2003.
} 


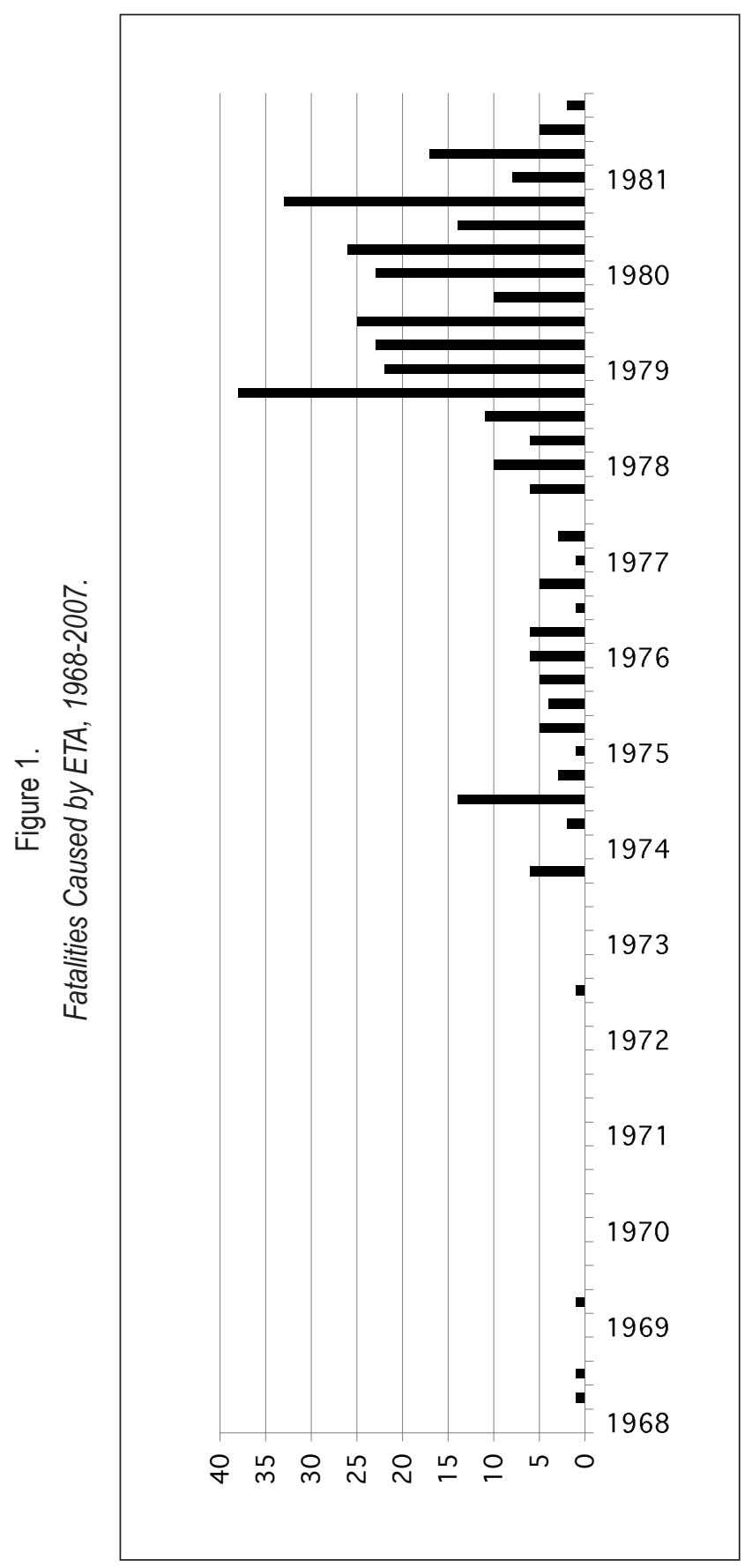

RIS, VOL. 67, № 3, SEPTIEMBRE-DICIEMBRE, 609-629, 2009. ISSN: 0034-9712 


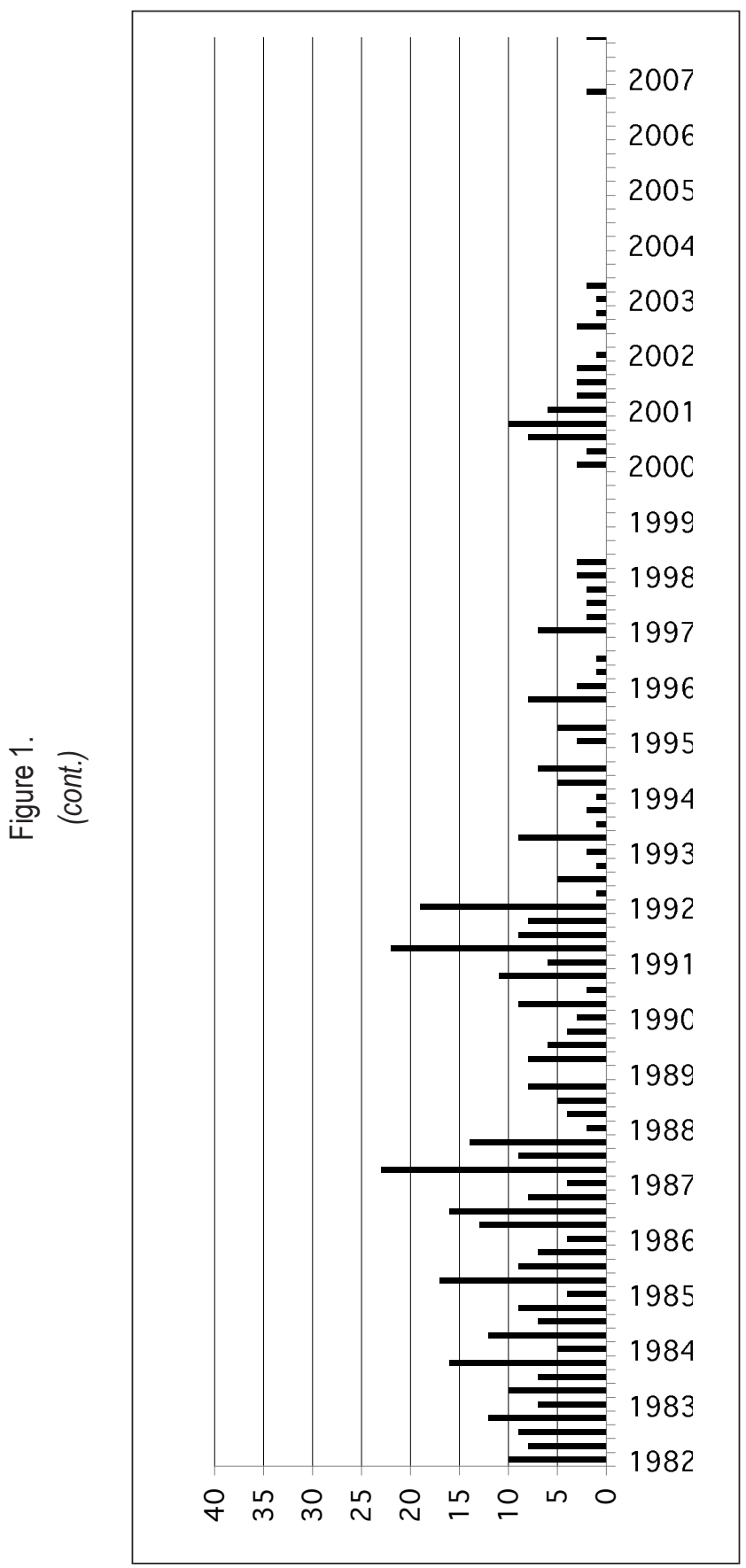


between 1982 and 1992 there is relative stability in the number of fatalities. There are, however, several important peaks, for example, in the second quarter of 1987 and in the second quarter of 1991 when the explosion of car bombs resulted in a high number of victims (the bombs in Hipercor in Barcelona and in the headquarters of the Civil Guard [Guardia Civi] in Vic, respectively). There is also a reduction in killings between 1988 and 1990 as a result of the talks between Felipe González's government and the terrorists; in the first quarter of 1989, ETA declared a ceasefire making possible a total of 6 meetings in Algiers, meetings which, all things considered, were of no avail.

The fourth phase begins with the fall of ETA's leadership in a police operation in Bidart in the south of France on 29 March, 1992. That year, in order to take advantage of the fact that Spain was to be at the centre of international attention due to the celebration of the Olympic Games in Barcelona and the Universal Exhibition in Seville, ETA planned to exert the maximum pressure possible on the State. The police operation in Bidart, however, spoiled all such plans. As can clearly be seen in Figure 1, in the second quarter of 1992 there was a drastic drop in the number of fatalities. ETA never recovered from Bidart. Indeed, ETA has never again displayed the levels of lethal violence of the two preceding phases, those corresponding to the period 1977-92.

In the years following Bidart, the terrorists attempted to reformulate their strategy, adapting it to the new circumstances. ETA accepted the impossibility of gaining independence by the pressure of arms alone and decided to join forces with the moderate nationalist parties. The aim was to forge a broad nationalist front capable of bringing about a political crisis within the State from which independence might spring. This new strategy materialized in the form of the Lizarra Pact (on 12 September, 1998) and ETA's later ceasefire.

From the point of view of violence, ETA significantly changed its pattern of victim selection in this new phase. Until 1992, violence was used to put pressure on the State: the preferred targets were the police, the Guardia Civil and the army. After the fall at Bidart, the terrorists decided to change tactic and carry out attacks on state representatives and officials. While politicians and state officials form only $2.6 \%$ of fatalities during the war of attrition (1977-1992), this figure reaches $21.7 \%$ during the following phase (1992-2007).

This change in victim selection comes about for two reasons. On the one hand, attacks carried out against state representatives (councilors) and officials (judges, public prosecutors) have a greater impact on public opinion (as theorized in the so-called "socialization of suffering strategy") than attacks against security forces. ETA, with its debilitated capacity for attack, was forced to turn on soft targets with tremendous social repercussions. On the other hand, attacks carried out against non-nationalist politicians proved to be useful for the nationalist front strategy in that they polarized the Basque Country, creating conflict between those who are nationalist and those who are not.

The inability to develop the nationalist front with moderate nationalists forced ETA to end its ceasefire in November 1999. As such, a new cycle of violence began, although much more limited in scope and length than previous ones. The offensive was mainly concentrated in the last quarter of 2000 and the first two quarters of 2001 and it was very 
quickly put down by the security forces. Since 2003 the intensity of ETA's lethal violence has been very low. Indeed, it could be said that the terrorist organization has entered a terminal phase: it has no strategy with which to substitute the nationalist front tactic and the security forces are seriously damaging its capacity to operate.

\section{TIME-SERIES STATISTICAL ANALYSIS}

I have carried out a statistical analysis using the time-series of fatalities of all Basque terrorist organizations. There is a total of 160 observations between the first quarter of 1968 and the last quarter of 2007. The dependent variable is the number of fatalities per quarter. It could be argued that the lethality of attacks can vary as a result of random factors (a car bomb may produce a massacre or it may kill only one person) and as such it would be more accurate to count the number of attacks and not the number of victims. In the case of ETA, there is no great difference between either of these indicators given that this terrorist organization has always been rather selective 6 : by the end of 2007, ETA had carried out 597 lethal attacks, killing a total of 836 people, which is an average of 1.4 fatalities per lethal attack. Furthermore, if we only take into account the number of attacks, we are assuming that ETA does not consciously decide on the degree of lethality of its attacks, a clearly questionable assumption to make. We know, for example, that the terrorists decided to use car bombs during the 1980s in order to increase the number of victims and reduce to a minimum the risk of being arrested. As such, the lethality of an attack is a feature that ETA seems clearly to take into consideration. In any case, I have carried out the analysis using both dependent variables, and the results for both cases are very similar.

With regard the independent variables, first of all, I have taken into consideration the different phases of ETA violence. Thus, the variable Franco refers to the years of the dictatorship (value 1 from the first quarter of 1968 until the second quarter of 1977, the date of the first democratic elections in Spain, and 0 thereafter). The variable Bidart refers to the phase following the fall of the organization's leadership (value 1 after the second quarter of 1992 and 0 beforehand). The two remaining phases implicitly defined by Franco and Bidart are those that refer in strategic terms to the war of attrition (from the third quarter of 1977 until the first of 1992). As mentioned above, during the war of attrition I separate a first phase involving a very strong offensive against the Government, which coincides with the final period of the transition to democracy ending in 1981, and a second phase of relative equilibrium between ETA and the State, stretching from 1982 to 1992. These two phases can be put together in a single one as strategically there is virtually no difference between them. From a statistical point of view, the joint effect of the two phases of the war of attrition is determined by the value of the intercept.

\footnotetext{
${ }^{6}$ The correlation per quarter between the number of fatalities and the number of lethal attacks is 0.93 .
} 
Table 1.

ARIMA Models. Dependent variable: quarterly number of fatalities

\begin{tabular}{|c|c|c|c|}
\hline & Model 1 & Model 2 & Model 3 \\
\hline Intercept & $\begin{array}{l}8.334^{\star * *} \\
(1.244)\end{array}$ & $\begin{array}{l}3.593 \\
(2.725)\end{array}$ & $\begin{array}{l}4.048 \\
(2.488)\end{array}$ \\
\hline Franco & $\begin{array}{l}-6.507^{* * *} \\
(1.367)\end{array}$ & $\begin{array}{l}-5.069^{* \star *} \\
(1.529)\end{array}$ & $\begin{array}{l}-5.156^{\star * *} \\
(1.343)\end{array}$ \\
\hline Bidart & $\begin{array}{l}-6.707^{\star * *} \\
(1.420)\end{array}$ & $\begin{array}{l}-5.877^{\star \star \star} \\
(1.412)\end{array}$ & $\begin{array}{l}-5.740^{* * *} \\
(1.085)\end{array}$ \\
\hline General elections & $\begin{array}{l}3.627^{* *} \\
(1.596)\end{array}$ & $\begin{array}{l}3.545^{\star *} \\
(1.587)\end{array}$ & $\begin{array}{l}3.317^{* \star} \\
(1.487)\end{array}$ \\
\hline European elections & $\begin{array}{l}2.113 \\
(1.745)\end{array}$ & $\begin{array}{l}1.910 \\
(1.759)\end{array}$ & -- \\
\hline Local elections & $\begin{array}{l}4.395^{* *} \\
(1.994)\end{array}$ & $\begin{array}{l}4.503^{* *} \\
(2.065)\end{array}$ & $\begin{array}{l}5.346^{* *} \\
(2.120)\end{array}$ \\
\hline Regional elections & $\begin{array}{l}-0.443 \\
(1.465)\end{array}$ & $\begin{array}{l}-0.491 \\
(1.492)\end{array}$ & -- \\
\hline Constref & $\begin{array}{l}27.42^{* * *} \\
(2.634)\end{array}$ & $\begin{array}{l}28.067^{* * *} \\
(2.460)\end{array}$ & $\begin{array}{l}26.774^{* * *} \\
(2.034)\end{array}$ \\
\hline Guernicaref & $\begin{array}{l}2.775 \\
(10.263)\end{array}$ & $\begin{array}{l}4.631 \\
(9.866)\end{array}$ & -- \\
\hline Extremeright & $\begin{array}{l}2.166^{* * *} \\
(0.726)\end{array}$ & $\begin{array}{l}2.262^{* * *} \\
(0.694)\end{array}$ & $\begin{array}{l}1.651^{* * *} \\
(0.585)\end{array}$ \\
\hline Extremeright $(t-1)$ & & & $\begin{array}{l}1.482^{* *} \\
(0.741)\end{array}$ \\
\hline GAL & $\begin{array}{l}0.662 \\
(0.531)\end{array}$ & $\begin{array}{l}0.564 \\
(0.535)\end{array}$ & -- \\
\hline Ceasefire & $\begin{array}{l}-2.343^{* *} \\
(0.997)\end{array}$ & $\begin{array}{l}-1.958^{* *} \\
(0.990)\end{array}$ & $\begin{array}{l}-2.198^{* *} \\
(0,965)\end{array}$ \\
\hline Larrests & & $\begin{array}{l}1.083^{* *} \\
(0.547)\end{array}$ & $\begin{array}{l}1.091 \\
(1.02)\end{array}$ \\
\hline Larrests $(t-1)$ & & & $\begin{array}{l}-0.142 \\
(0.910)\end{array}$ \\
\hline$A R(1)$ & $\begin{array}{l}0.662^{* * *} \\
(0.138)\end{array}$ & $\begin{array}{l}0.605^{* * *} \\
(0.167)\end{array}$ & $\begin{array}{l}0.583^{* * *} \\
(0.126)\end{array}$ \\
\hline $\mathrm{MA}(1)$ & $\begin{array}{l}-0.768^{* * *} \\
(0.149)\end{array}$ & $\begin{array}{l}-0.734^{* * *} \\
(0.179)\end{array}$ & $\begin{array}{l}-0.658^{* * *} \\
(0.160)\end{array}$ \\
\hline $\mathrm{MA}(2)$ & $\begin{array}{l}0.343^{* *} \\
(0.153)\end{array}$ & $\begin{array}{l}0.312^{*} \\
(0.161)\end{array}$ & $\begin{array}{l}0.229^{*} \\
(0.122)\end{array}$ \\
\hline $\begin{array}{l}\text { Standard deviation of the } \\
\text { residuals }\end{array}$ & $\begin{array}{l}3.719^{* * *} \\
(0.153)\end{array}$ & $\begin{array}{l}3.691^{* * *} \\
(0.281)\end{array}$ & $\begin{array}{l}3.572^{* * *} \\
(0.122)\end{array}$ \\
\hline $\mathrm{N}$ & 160 & 160 & 159 \\
\hline
\end{tabular}

Standard robust errors in brackets.

${ }^{* * *}=$ significant at $1 \% ;{ }^{* *}=$ significant at $5 \% ;{ }^{*}=$ significant at $1 \%$. 
During the war of attrition phase as well as that of the nationalist front, ETA declared several ceasefires: one between January and April in 1989, another between September 1998 and November 1999, and another between March 2006 and June 20077. The variable ceasefire takes value 1 in all the periods in which ETA formally declared a ceasefire which lasted for at least one month. It is essential that this variable be taken into account given that an end to killings during a ceasefire is not the result of external factors (such as police arrests) which curtail ETA's activity against its will, but the result of a decision by the terrorists themselves.

Secondly, I have included independent variables that capture the effects of certain relevant events, such as the referendum on the Constitution (Constref) and the referendum on the Statute of Autonomy (Guernicaref), which may have influenced ETA in terms of the intensity of its violence. In this sense, it is important to emphasize that the referendum on the Constitution was held on 6 December 1978, during the bloodiest quarter in ETA's entire history. With regard the referendum on the Statute of Autonomy of the Basque Country (the Statute of Guernica), this was held on 25 October 1979, coinciding with a noticeable reduction in the number of fatalities of this quarter compared to the previous one and that which followed (see Figure 1).

Thirdly, the model includes variables that capture the effects of the celebration of all types of elections: general, Basque regional, local, and European elections. The aim is to determine if ETA increased or decreased its lethal activity during election periods. Given that these referendums as well as the elections could easily be held at the beginning of a quarter, it would be incorrect to attribute all the violence in the corresponding quarter to such events, and so I have applied the following rule: if the event takes place in the first half of the quarter, that quarter as well as the previous one takes the value 0.5 ; and, if the event takes place in the second half of the quarter, that quarter takes the value 1 and the previous one 0 .

We know that at certain moments in ETA's cycle of violence, the dirty war was going on. The best known case is that of the Anti-Terrorist Liberation Groups (GAL-Grupos Antiterroristas de Liberación), which operated between 1983 and 1987, killing 27 people, many of whom had no relationship whatsoever with ETA (Woodworth, 2001). Before the GAL, however, there were several plots by extreme right-wing groups and the security forces, under diverse banners, to attack members of ETA or people connected with the radical nationalist movement. In fact, Sánchez-Cuenca and Aguilar (forthcoming) estimate 34 fatalities between 1975 and 1982. Thus, a total of 61 fatalities can be attributed to antiETA terrorism. The variable GAL captures the quarterly number of fatalities of the dirty war. The variable extremeright captures the equivalent number in the cycle of extreme right-wing anti-ETA violence.

\footnotetext{
${ }^{7}$ These ceasefires have been codified according to ETA's declarations, not its actions. Thus, in the case of the permanent ceasefire of 2006, I consider that this was in force until the formal declaration of its end on 5 June 2007, despite the fact that during the ceasefire ETA killed two people in a car bomb explosion in the car park of Madrid's Barajas airport on 30 December 2006.
} 
A variable which is fundamental to the analysis of variations in ETA violence is the antiterrorist activity of the State, that is, the number of arrests that the security forces make. Unfortunately there are no quality data on arrests. The Home Office made an annual series of arrests in Spain and France for the period 1968-2001 available in its web page for a time. This is the source I have used. As there are no quarterly data available, I evenly distribute then the annual number of arrests over the four quarters of each year. The variable is measured in logarithms as there are large variations between some periods and others.

Furthermore, the existing data do not distinguish between arrests which end in legal proceedings and arrests where the detainees are released without charge. Given that the thoroughness of police work has not been uniform over time ${ }^{8}$, we can conclude that these data are, at best, a very rough approximation of police efficiency in the fight against ETA.

The analysis of the fatalities series has been carried out using ARIMA models, which take into account the possible time dependence between observations. It makes no sense, in the case of a terrorist organization, to consider that the number of fatalities in a given period of time is independent of the number of fatalities in previous periods. As such, it is essential that time-series analysis techniques be used ${ }^{9}$.

The Dickey-Fuller test shows that the fatalities series is stationary, and as such it is not necessary to take first differences of the dependent variable. From the analysis of the correlogram and several estimations, I can conclude that the behavior of the series corresponds to that of an $\operatorname{ARIMA}(1,0,2)$ model, that is, it has one auto-regressive term and two moving average terms. The residuals of the model are white noise.

Table 1 contains the results when several combinations of independent variables are introduced into the ARIMA models. The first model statistically confirms that the phase prior to the first democratic elections of 1977 (the Franco variable) as well as the phase after the fall at Bidart in 1992 (the Bidart variable) have a significantly lower average of fatalities than the central period covering the war of attrition. The Franco and the postBidart phases have a quarterly decrease of 6.5 and 7 fatalities, respectively, compared to the central period. The ceasefire variable, as expected, also has a significant and negative effect on the number of fatalities.

As mentioned above, the bloodiest quarter of all is the fourth quarter of 1978, which coincides with the referendum on the Constitution. The coefficient of this dummy variable is very strong and highly significant. The increase in violence in this quarter, thus, cannot be explained by the dynamic nature of the series alone, but by some external event, which in this case may be attributed to the Constitution. In line with this interpretation, ETA would have embarked on a campaign of creating an atmosphere of demoralization and fear in order to reduce participation in the referendum.

\footnotetext{
${ }^{8}$ Domínguez (1998a: 215) shows, using data from the period 1982-1992, that the percentage of arrests ending in legal proceedings have been increasing over the years.

${ }_{9}^{9}$ Martínez Herrera (2007), with annual data, carries out estimations using negative binomial regression techniques, which assume independence between observations.
} 
Applying the same reasoning, the reduction in the level of violence in the fourth quarter of 1979 may have been due to ETA's desire not to interfere in the referendum on the Statute of Autonomy. However, the coefficient of this variable is not significant, meaning that the reduction observed in this quarter is not sufficiently large to conclude that it is coming from the dynamic nature of the time series.

With regard electoral periods, there are a number of new and interesting findings. The coefficients of the general and local elections are positive and significant, indicating that ETA increases violence in the periods leading up to such types of elections. We know that local power is especially important for ETA, due to the territorial control and the control over daily life that it affords. This type of control is essential for the social reproduction of the terrorist organization. The case of the general elections though is different: ETA intervenes to ensure maximum possible publicity and presence during the Spanish electoral period.

Why are the coefficients of the European and Basque regional elections not significant? As the European elections are of little importance in Spanish politics, it is not surprising that ETA does not react to them. With regard the regional elections, it is interesting to note that this variable is the only one of all the election variables that has a negative coefficient, although it is not significant. It would seem then that there is a tendency to reduce violence somewhat in this type of elections, perhaps because they are the only institution which is entirely Basque, and so ETA anticipates a certain lack of understanding toward any interference in them.

Finally, it is important to emphasize that the cycles of anti-ETA violence have very different effects. While the GAL coefficient is not significant, the extremeright coefficient is. The dirty war carried out by the GAL, largely organized and controlled by the Home Office of Felipe González's government, has no effect on ETA's cycle of violence. It made no difference to ETA's violence and neither was it a reaction to it ${ }^{10}$. However, the less organized and more spontaneous violence of the extreme right wing in the period 1978-82 did have an effect on ETA's activity. This coefficient has a positive sign, indicating that in the short term relationship between the two variables an increase in fatalities of extreme right-wing groups is associated with an increase in the fatalities of ETA. As we shall see later, it is essential that the data be analyzed in more detail in order to understand the direction in which this influence flows; whether the extreme right reacts to attacks launched by ETA, or vice versa.

In Model 2 in Table 1, the logarithm of arrests (larrests) has been added to the list of independent variables. It does not produce important changes in the rest of the independent variables The coefficient is positive and significant: detainees and fatalities are associated in the short run. A plausible interpretation of this relationship is this: the

\footnotetext{
${ }^{10}$ This does not mean to say that it did not have other important consequences. It is thought, for example, that the matter of the GAL strengthened in the short and medium term the popular support for ETA and damaged the legitimacy of the State in the Basque Country.
} 
more ETA kills, the more exposed the terrorists are and consequently the more numerous police arrests will be.

In terms of both extreme right-wing terrorism and police arrests, it is not sufficient to analyze the short term relationship between the two variables. What we are interested in is uncovering the direction of the causality of ETA's violence. To shed some light on this question, I introduce in Model 3 in Table 1 a first lag in these two independent variables.

Beginning with extreme right-wing terrorism, we can see that the first lag is also positive and significant. As such, this type of terrorism is not simply a reaction to ETA's activity, it produces changes in it ${ }^{11}$. As the lag is positive, we can conclude that ETA increases its level of lethal violence after lethal attacks by the extreme right wing. Violence by the extreme right with regards ETA does not reduce the lethality of ETA, quite the opposite: it would seem that it sparks off a spiral of acts of vengeance. Nothing similar occurs with the GAL, as neither the short term relationship nor the lags are significant.

In terms of arrests, Model 3 shows that neither the original variable nor the lagged variable influence the number of fatalities at the hands of ETA. I have tested with multiple combinations of lags but not one has produced a significant relationship. As such, we cannot conclude from a statistical point of view, probably due to the bad quality of the data on arrests, that these produce a reduction in the lethal activity of ETA. We can only conclude that the more ETA kills, the greater the number of arrests ${ }^{12}$.

The results of the ARIMA analysis are quite solid: fundamentally, the same findings are obtained using first differences models. An ARIMA(1, 1, 1) model produces identical conclusions about the effects of the independent variables. The fact that almost nothing changes when first differences are introduced is important in concluding that the results obtained are not an artificial effect produced by the statistical model used.

In summary, the analysis of the time series of fatalities allows us to conclude the following: (i) that the Franco phase as well as the phase following the events at Bidart have a significantly lower number of fatalities compared to the period covering the war of attrition; (ii) that ETA reacted to the referendum on the Constitution in 1978 by stepping up the level of violence (however, there is no significant statistical change with regard the Statute of Autonomy); (iii) that ETA increases lethal violence before general and local elections; (iv) that extreme right-wing terrorism, although not that of the GAL, is a reaction to the lethal activity of ETA but it also produces an increase in it; and finally (v) that the number of police arrests is greater the more ETA kills, although it cannot be statistically proved that this reduces ETA's lethal capacity.

\footnotetext{
${ }^{11}$ Granger's causality test applied to a VAR (Vector Autoregressive) model with ETA and extreme rightwing fatalities shows that the causality is bi-directional: the extreme right kills more when ETA increases its terrorist activity and, at the same time, ETA kills more after attacks from the extreme right. The results of this analysis are available on request.

${ }^{12}$ Sánchez-Cuenca (2007a) comes to the same conclusion with annual data, although it is shown that if the dependent variable is the annual series of the total number of actions of ETA, arrests do cause a reduction in ETA's terrorist activity.
} 


\section{Historical-Political Analysis}

As mentioned above, ETA's great offensive was launched at the end of 1977 and waned in 1981. This period contains the greatest concentration of fatalities in ETA's entire history. This very intense cycle of violence occurred during the transition to democracy, broadly understood to be the period between the death of Franco and the victory of the PSOE in the 1982 elections. Given the importance of this offensive as well as the political context in which it took place, I offer a more in-depth explanation than the one provided by the statistical analysis in the previous section. Indeed, there are two fundamental questions that can only be answered by a detailed examination of the events of the time.

The first question is: why does ETA begin its offensive against the State so late on in the transition? Initially, it would seem logical to assume that if ETA's real interest is to gain the independence of the Basque Country, armed terrorist violence would have had a greater effect when the rules of the game were not yet defined and there was a great deal of political uncertainty. However, the great offensive began after the first democratic elections of June 1977 and, more interestingly, after the approval of the Constitution in December of the following year. The second question is: why was there such a drastic drop in the number of lethal attacks during 1981? Why was the intensity of the great offensive launched during the final phase of the transition reduced only four years after it began without ETA having won any kind of political victory?

\section{The conditions of the Great Offensive of 1977}

There is abundant literature supporting the idea that political violence (wars, civil wars, terrorism) increases in regimes in transition or in mixed regimes (known as "anocracies", regimes which mix authoritarian and democratic elements) (Fearon and Laitin, 2003; Gleditsch, Hegre and Strand, forthcoming; Gurr, 1993; Hegre et al., 2001; Mansfield and Snyder, 1995; Muller and Weede, 1990; Snyder, 2000). The mechanism that accounts for this relationship is the following. Under a dictatorship, repression is so great that it deters potential rebels and as a result there is no violent protest. In consolidated democracies, on the other hand, repression is very low, meaning that the existing political opportunities favor pacific collective action. In a regime in transition, however, the State loses part of its repressive power while the rights which guarantee pacific protest are still not fully in place. When protest does happen, it can very easily become violent.

Thus the hypothesis is that the relationship between violence and civil rights has an inverted "U" shape. This very general scheme fits to a certain degree the experience of ETA in Spain, although with a certain time lag, given that most of ETA's killings are concentrated in the final phase of the transition, after the first democratic elections in June 1977, and consequently when Franco's regime finally came to an end. Between the election victory of the UCD in June 1977 and that of the PSOE in October 1982, just over five years, ETA killed 321 people, $38.4 \%$ of its total killings. Figure 1 clearly illustrates the inverted $U$ shape of the killings in the transition period. 
What is strange, in this sense, is that the violence comes so late on and that the death of Franco is not accompanied in the short term by an increase in the activity of ETA, but rather a slight drop in the lethal violence between the third quarter of 1976 and the third of $1977^{13}$. In my opinion, three factors explain this lag: (i) organizational problems, (ii) the relationship between the different Basque nationalist forces, and (iii) the relationship between popular mobilization and terrorist violence.

Starting with the internal reasons, it is necessary to remember that ETA split into two independent organizations, ETA-m and ETA-pm, at the end of 1974. The majority, in favor of combining armed struggle with institutional political struggle, formed ETA-pm. The minority, in favor of a purely military route, formed ETA-m. And precisely because they were a minority, those who had greater incentives to increase the violence after the death of Franco were unable to do so. Their problems with obtaining arms and recruiting activists were not resolved until May 1977 when a new split occurred, this time in the heart of ETA-pm. Given the dominant preference for political struggle over armed struggle within ETA-pm, the military commands, the so-called bereziak (special commands), decided to abandon the organization and go over with their arms to ETA-m. Without the entry of these militants, ETA-m would not have been able to launch its brutal offensive at the end of that year.

Secondly, we need to take into account that at the beginning of the transition, the different Basque nationalist forces tried to act in conjunction, forming a more or less united front in the first general elections. In such circumstances, the terrorists could not start a campaign of violence without destroying all hope of unity. The PNV wanted to attract both branches of ETA towards institutional politics, thus ensuring that all the Basque nationalist groups would accept the democratic route and fight for a devolution process for the Basque Country. In May 1977 just before the general elections of that year, the different groups discussed in the Chiberta Hotel, in Anglet (the French Basque Country), the possibility of coordinating their strategies (Casanova and Asensio, 2002: 276-80; De Pablo, Mees and Rodríguez, 2001: 340-46; Letamendía, 1994: 34-5) ${ }^{14}$.

They could not reach an agreement. The calling of the elections produced a clear separation between the different positions held within Basque nationalism. From the very beginning the PNV was in favor of participating. At the other extreme, ETA-m demanded as a necessary condition for participation that the Suárez government award total amnesty and legalize all parties. ETA-pm adopted an intermediate position and agreed to participate (through Euskadiko Eskerra) in exchange for partial concessions: the lawyer Juan María Bandrés reached an agreement with the government to release several members of ETA from prison on condition that they left the country (a sort of exile).

\footnotetext{
${ }^{13}$ Authors sympathetic to ETA speak of a tacit ceasefire beginning in the summer of 1976 as the result of a need to build a united nationalist political movement for the new era of democracy (Casanova and Asensio, 2002: 257).

${ }^{14}$ To see how important the meeting in Chiberta still is for the radical nationalist movement, see Otegi, Iriondo and Sola (2005: 17-23).
} 
The split between nationalist moderates (or pragmatists) and radicals (or intransigents) was completed in the clash of two demonstrations in San Sebastian on 8 September 1977 , one organized by the moderates, in favor of an autonomous regime for the Basque Country, and the other by the radicals, in memory of Josu Zabala, killed one year before by the Guardia Civil (Civil Guard) during a demonstration. There were insults, clashes, even blows (Letamendía 1994: 58). This deep division was the prelude to the great offensive of ETA-m months later.

It is interesting to remember that in the case of Italy something very similar occurred. The eruption of violence in the years 1977-1980 was sparked off by a brutal clash in the University of Rome, which had been occupied by the students, between the $\mathrm{PCl}$ (the Italian Communist Party) and extreme left-wing groups on 17 February 1977 (Ballestrini and Moroni, 1997: 536-41; Boraso, 2006: 105-08). That clash was the result, as in the Basque case, of the decision of the moderate sector (the PCl) to become institutionally involved in the governing of the country by supporting the Christian Democrats. That decision separated for once and for all the moderates from the radicals.

Thirdly, ETA launched its campaign after experiencing a large drop in popular mobilization $^{15}$. Some authors (Tarrow, 1989; Della Porta, 1995) have pointed out that violence in social movements emerges during the ebbing of mobilizations. The spring and summer of 1977 saw the largest demonstrations ever held until then in the Basque Country. The common denominator of them all was the struggle for total amnesty for prisoners and protests against the repressive excesses of the State (killings in demonstrations, road controls, etc.). During the summer, for example, the so-called "Freedom March" was organized (different wings of the march leaving from different locations, marching for three weeks all over the Basque Country, until they all finally met up in a gigantic demonstration in the outskirts of Pamplona).

The celebration of the general elections, with the participation of the main parties, the PNV, the EE and the PSOE, as well as the amnesty approved by Parliament in October 1977, rapidly reduced collective protests. ETA-m, in the $69^{\text {th }}$ edition of its internal publication Zutik, explained the strategy of the war of attrition against the State, referring to the drastic drop in mobilizations: "After the Freedom March and the latest demonstrations for amnesty, popular mobilizations plummeted and the masses shifted from actors to spectators in the parliamentary game". In the face of the passive attitude in society, ETA-m set itself up as the protagonist in an attempt to bring about the failure of the institutional reforms of the transition period.

\footnotetext{
${ }^{15}$ In Sánchez-Cuenca and Aguilar (forthcoming), we analyze the relationship between lethal violence and the rate of demonstrations for the period 1975-82. Thanks to a very detailed database on demonstrations held between 1976 and 1978, we show how ETA's great offensive took place immediately after a large and rapid drop in the rate of demonstrations in the Basque Country in defense of the amnesty.
} 


\section{The end of the transition: the fall of 1981}

In Figure 1 we can see that in 1981 the level of ETA's lethal violence dropped drastically. Why did such a drop come about? It is important to note that this was not limited to ETA alone. A drop is also present in extreme right-wing and left-wing terrorism, and even in state repression. Obviously, the most extraordinary event of that year was the failed coup d'etat of 23 February. It would seem logical to assume then that this was the cause of the decrease in lethal violence (Martínez Herrera, 2007). This could be confirmed, for example, by the fact that ETA-pm renounced violence due to the attempted coup.

However, there are several issues which lead me to believe that the problem is somewhat more complex than this ${ }^{16}$. First of all, ETA-m did not stop killing soldiers. Less than one month later, ETA killed two soldiers of lieutenant colonel rank in two separate attacks (Román Rotaeche and José Luis Prieto). On 7 May there was a failed attempt to kill lieutenant general Valenzuela; however, three other soldiers were killed in the attack, one of them a lieutenant colonel. In fact, the percentage of military victims with regard the annual total is much higher in 1981 (25\%) than in 1980 or 1982 (approximately 10\% in both years). This figure does not support the thesis that ETA reduced its violence due to the fear of a military threat. Secondly, the number of fatalities increased, not decreased, during the second quarter of 1981 . The real drop came later, in the third and especially the fourth quarters of that year. The increase in the second quarter is incompatible with the thesis of the impact of the failed coup. Finally, there is no mention of fear of the coup in any of ETA's internal documents of the time.

I have introduced into the statistical analysis of the time series a dummy variable that takes value 1 in the quarter of the coup and 0 in the rest. If enough lags are added, the coefficients are negative and significant (except for the first, which is strongly positive due to the increase in the lethality of the second quarter), coinciding with the drop in the number of fatalities in 1981. However, I feel that this procedure is questionable, given that, for the reasons just mentioned, there is not sufficient proof for believing that the attempted coup had a direct causal effect on ETA activity. The statistical significance, in this case, could reflect a coincidence, and not a substantive relationship between the variables.

In my opinion, it is essential to bear in mind that, apart from the coup, 1981 stands out for the very high number of arrests made. It is the year with the greatest number of arrests of the entire period: according to Home Office figures, 714 people were arrested, compared to an annual average of 222 ( 1981 alone represents almost $9 \%$ of total arrests). It would seem logical to assume that the decrease in lethal attacks in 1981 was the result

\footnotetext{
${ }^{16}$ The coup thesis, if it were true, would imply, contrary to what has almost always been claimed, that ETA did not intend to provoke a military uprising through its attacks. If the objective was to destroy the democracy, the failed coup of 23 February should have caused ETA to increase, not decrease, its violence (on this matter, see Sánchez-Cuenca, 2001: 67-72).
} 
of ETA's inability to recover from these many arrests. Bearing in mind that, as mentioned above, a greater number of attacks leads to a greater number of police arrests, we may conclude that ETA did not have sufficient resources to keep up the rhythm of killings set in the first three years of the offensive. This would explain the drop in 1981, which is comparable in size only to the drop which occurred in 1992 immediately after the capture of ETA's leadership at Bidart.

\section{Conclusions}

Thanks to the creation of a database of the fatalities of ETA and its different branches and splinter groups, it has been possible to carry out an analysis of the time series of killings. The use of quarterly data (compared to annual data) has allowed me to determine the causal weight of several factors associated with terrorism which until now were unknown or were unable to be demonstrated, such as the effect of the referendum on the Constitution in December 1978, the various effects of different types of elections, and the effects of the anti-ETA violence of extreme right-wing groups and the GAL, a para-state organization. Moreover, the analysis reveals that there were four distinct phases in terms of the intensity of violence. These phases are clearly related to the strategic development of ETA. They are as follows: (i) that which belongs to Franco's regime, based on the strategy of action-repression-action; (ii) the great offensive against the State, between 1977 and 1981, which marks the beginning of the war of attrition; (iii) the phase of prolonged conflict between 1982 and 1992, which stabilizes the war of attrition; and (iv) the process of decline which began after the fall at Bidart in 1992, marked first by the attempt to forge a broad nationalist front and, after the failure of this front, marked by the simple strategic deterioration which is inherent at the end of any terrorist organization.

The violence is mostly concentrated in phases (ii) and (iii), those which correspond to the war of attrition. The statistical analysis shows that the violence during Franco's regime and after the fall at Bidart is significantly lower than during the war of attrition. The effect of Bidart is not circumstantial, it is structural: ETA has never recovered from this blow.

Obviously, the statistical analysis has certain limitations. On the one hand, everything which cannot be measured numerically has been left out of the analysis, while, on the other hand, some of the numerical measures are questionable. Conscious of these limitations, I have tried to complement the statistical treatment of the data with a historicalpolitical analysis. In particular, I have chosen, given the limitations of space of an article of this nature, to focus on the most complex and intense period of terrorist violence; that covering the years 1977-1981. It is in this period that ETA launches its great offensive in the form of a war of attrition and in this same period that the State manages to contain and reduce this war. 
As I have tried to show, there are several factors which help to explain the increase in ETA terrorism after 1977: first, the end of internal organizational problems brought on by several splits; secondly, the division in Basque nationalism between moderates and radicals as a result of the decisions which the different groups made regarding participation in the general elections of 1977; and third, the drop in popular mobilizations in favor of the amnesty.

With regard the drastic drop in the number of fatalities in 1981, this may in part be due to the attempted coup in February of that year. However, even more important in my opinion is the high number of arrests made as a result of the extremely high levels of violence of the previous years. To a certain extent, this drop may be due to ETA's inability to keep up the rhythm of killings started in 1977.

This historical-political analysis is not incompatible with the previous statistical one, quite the contrary. Both analyses complement each other reasonably well. A full and complete history of the cycle of violence of ETA should be based on numerical data as well as historical and political narration. This task has yet to be done. This article is simply a first step in this direction.

\section{REFERENCES}

Avilés Farré, J. 2005. "El terrorismo en la España democrática". In J. Tusell (coord.), La transición a la democracia y el reinado de Juan Carlos I, Volume XLII of Historia de España de Menéndez Pidal, pp. 632-665. Madrid: Espasa.

Ballestrini, N. and P. Moroni. 1997. L’orda d’oro 1968-1977. Milán: Feltrinelli.

Barros, C. 2003. "An Intervention Analysis of Terrorism: The Spanish ETA Case". Defence and Peace Economics 14: 401-412.

Barros, C., J. Passos and L. Gil-Alanal. 2006. "The timing of ETA terrorist attacks". Journal of Policy Modeling 28: 335-346.

Barros, C. and L. Gil-Alana. 2006. "ETA: A Persisten Phenomenon". Defence and Peace Economics 17: 95-116.

Boraso, G. 2006. Mucchio Selvaggio. Ascesa apoteosis caduta dell'organizzazione Prima Linea. Roma: Castelvecchi.

Calleja, J.M. and I. Sánchez-Cuenca. 2006. La derrota de ETA. Madrid: AdHara.

Casanova, I. and P. Asensio. 2002. Argala. Tafalla: Txalaparta.

De la Calle, L. and I. Sánchez-Cuenca. 2004. "La selección de víctimas en ETA". Revista Española de Ciencia Política 10: 53-79. 
De la Calle, L. 2007. "Fighting for Local Control: Street Violence in the Basque Country". International Studies Quarterly 51: 431-455.

Della Porta, D. 1995. Social Movements, Political Violence, and The State. A Comparative Analysis of Italy and Germany. Cambridge: Cambridge University Press.

De Pablo, S., L. Mess and J. A. Rodríguez. 2001. El péndulo patriótico. Historia del Partido Nacionalista Vasco, II: 1936-1979. Barcelona: Crítica.

Domínguez, F. 1998a. ETA: Estrategia organizativa y actuaciones. 1978-1992. Bilbao: Universidad del País Vasco.

Domínguez, F. 1998b. De la negociación a la tregua. ¿El final de ETA?. Madrid: Taurus.

Elorza, A. (coord.). 2000. La Historia de ETA. Madrid: Temas de Hoy.

Fearon, J. and D. Laitin. 2003. "Ethnicity, Insurgency, and Civil War". American Political Science Review 97: 75-90.

Gleditsch, N. P., H. Hegre and H. Strand (en prensa), 'Democracy and Civil War', in M. Midlarsky (coord.), Handbook of War Studies III. Ann Arbor. University of Michigan Press.

Gurr, T. 1993. Minorities at Risk. A Global View of Ethnopolitical Conflicts. Washington (D.C.). Institute of Peace Press.

Hegre, H., T. Ellingsen, S. Gates and N. P. Gleditsch. 2001. "Toward a Democratic Civil Peace? Democracy, Political Change, and Civil War, 1816-1992". American Political Science Review 95: 33-48.

Jaime, O. 2002. Policía, terrorismo y cambio político en España, 1976-1996. Valencia: Tirant lo Blanch.

Letamendía, F. 1994. Historia del nacionalismo vasco y de ETA (Volumen II). San Sebastián: R\&B Ediciones.

Llera, F. 1992. "Violencia y opinión pública en el País Vasco, 1978-1992". Revista Internacional de Sociología 3: 82-111.

Mansfield, E.D. and J. Snyder. 1995. "Democratization and the Danger of War". International Security 20: $5-38$.

Beck, J. M. 2005. Territory and Terror. Conflicting Nationalisms in the Basque Country. London: Routledge.

Martínez, E. 2002. "Nationalist Extremism and Outcomes of State Policies in the Basque Country, 1979-2001". International Journal on Multicultural Studies 4: 16-41.

Martínez, E. 2007. "Government restructuring and reallocation of resources in the face of ethno-nationalist insurgency in the Basque Country (1979-2005)". En M.Oberg and K.Strom (coords.) Resources, Governance Structures and Civil Conflict, pp.101-124. London: Routledge.

Mata, J. M. 1993. El nacionalismo vasco radical. Discurso, organización y expresiones. Bilbao: Universidad del País Vasco.

RIS, VOL. 67, № 3, SEPTIEMBRE-DICIEMBRE, 609-629, 2009. ISSN: 0034-9712 
Muller, E. and E. Weede. 1990. "Cross-National Variation in Political Violence: A Rational Action Approach". Journal of Conflict Resolution 34: 624-651.

Otegi, A., I. Iriondo and R. Sola. 2005. Mañana, Euskal Herria. Entrevista con Arnaldo Otegi. Bilbao. Gara.

Reinares, F. 2001. Patriotas de la muerte. Quiénes han militado en ETA y por qué. Madrid: Taurus.

Reinares, F. and O. Jaime. 2000. "Countering Terrorism in a New Democracy: the Case of Spain". In F. Reinares (coord.) European Democracies Against Terrorism, pp.119-145. Aldershot: Dartmouth.

Sánchez-Cuenca, I. 2001. ETA contra el Estado. Las estrategias del terrorismo. Barcelona: Tusquets.

Sánchez-Cuenca, I. 2007a. "The Dynamics of Nationalist Terrorism: ETA and the IRA". Terrorism and Political Violence 19: 289-306.

Sánchez-Cuenca, I. 2007b. "Violencia política, orden y seguridad". In M. Pérez Yruela (coord.) La sociología en España, pp.289-303. Madrid: Centro de Investigaciones Sociológicas.

Sánchez-Cuenca, I. and P. Aguilar (forthcoming), "Terrorist Violence and Popular Mobilization. The Case of the Spanish Transition to Democracy", Politics \& Society.

Shabad, G. and F. Llera. 1995. "Political violence in a democratic state: Basque terrorism in Spain". In M. Crenshaw (coord.) Terrorism in context, pp. 410-469. University Park: The Pennsylvania State University Press.

Snyder, J. 2000. From Voting to Violence. Democratization and Nationalist Conflict. New York: Norton.

Tarrow, S. 1989. Democracy and Disorder. Protest and Politics in Italy, 1965-1975. Oxford: Clarendon Press.

Tejerina, B. 2001. "Protest cycle, political violence and social movements in the Basque Country". Nations and Nationalism 7: 39-57.

Woodworth, P. 2001. Dirty War, Clean Hands: ETA, the GAL and Spanish Democracy. Cork: Cork University Press.

IGNACIO SÁNCHEZ-CUENCA is Research Director in the Centre for Advanced Study in the Social Sciences at the Juan March Institute. He is also Associate Professor of Sociology at Complutense University (Madrid). He has been Rice Visiting Associate Professor at Yale University and Visiting Scholar at New York University. $\mathrm{He}$ is the author of several books, including ETA contra el Estado (Tusquets, 2001). He is co-editor (with J.M.Maravall) of Controlling Governments. Voters, Institutions, and Accountability (Cambridge University Press, 2008). He has published numerous articles in international and Spanish journals (Annual Review of Political Science, Journal of Peace Research, Government \& Opposition, Party Politics, European Union Politics, European Journal of Sociology, Revista Española de Investigaciones Sociológicas, Revista Internacional de Sociología, Revista Española de Ciencia Política, Revista de Estudios Políticos, and others).

RECEIVED: 24 March 2008

ACCEPTED: 26 November 2008

Published on-line: 20 July 2009 